\title{
A Brief Analysis of the Integration of Ideological and Political Education in College English Class
}

\author{
Yumei Tan \\ College of Foreign Languages and Cultures, Sichuan University, Chengdu, Sichuan, China \\ mariatan66@163.com
}

Keywords: Ideological and Political Education, College English, Reading, Listening, Translating, Writing

\begin{abstract}
Chinese government pays much attention to the students' ideological and political education. As an important public basic course in the universities and colleges, College English is widely learned by the students. College English is not only a foreign language learning course, but also has the responsibility of ideological and political education. It is possible to integrate ideological and political education in College English class. This paper finds a solution to integrate the ideological and political education into the reading, listening, speaking, translating and writing in the College English class.
\end{abstract}

\section{Introduction}

On January $27^{\text {th }}, 2017$, the National Congress issued the Suggestions On Strengthening and Improving Ideological and Political Work in Colleges and Universities under the New Situation (hereinafter referred to as Suggestions). The Suggestions said that the Universities and colleges should attach importance to the professional knowledge as well as the ideological and political education. The Suggestions also ask the universities and colleges to strengthen the management of the classes and make full use of the ideological and political resources in those classes. Therefore, Chinese government pays much attention to the students' ideological and political education. As an important public basic course in the universities and colleges, College English is widely learned by the students, and it is the course that students spend most of the time learning it. In July 2007, the Ministry of Education of the People's Republic of China issued the College English Teaching Requirements, and it pointed out that College English is not only a foreign language learning course, but also has the responsibility of ideological and political education. Since College English has a special position in the higher education, it is possible to integrate ideological and political education in College English class.

On the other hand, it is necessary to give the guidance to the college students. For the college students, they just enter a fresh new environment which is completely different from their previous study and life, and they are facing new challenges and their view of life will be easily influenced by their peers, teachers and the environment. Compared with the previous college students, they have more opportunities to bring into contact with the political, economic and cultural activities of other countries. During the interaction, their choice and judgment sometimes will be uninitialized and secularized. It is widely accepted that it is the responsibility of the ideological and political teacher and counselor to give the lessons on ideological and political education. In present College English class, English teachers also ignore this education. Therefore, it is necessary and important to find a solution to integrate the ideological and political education into the College English class.

\section{To Integrate the Ideological and Political Education in Reading}

English reading is very important in the whole learning process of the college English. The teachers can make full use of the intensive and extensive reading in the class and try to find the connection between the texts and the ideological and political education. Take New College English Integrated Course 1 published by Shanghai Foreign Language Education Press for example, the theme of unit 4 
is American Dream. The teacher can assign the homework to the students before they learn this lesson and ask them to give the definition of American Dream and discuss how American Dream is demonstrated in American novels, movies and real life. After they fully understand American Dream, then ask the students to make a comparison between American Dream and Chinese Dream. The students will get to know the spirit of Chinses Dream and they will be inspired to study hard to realize their own Chinese Dream.

The theme of unit 3 is understanding science. For this unit, the teacher can divide the students into several groups and ask each group to give the presentation on the development of one or two technologies and then to make full use of their wild imagination to design a product that can influence or change their life. By doing this, the students will have a better understanding of the development of some important technologies in history and will have a good attitude toward the modern technology. Only if they have the heart of awe toward science and realize that our human civilization can live on if they study hard on the framework of science in colleges. The teacher can also recommend the students to read some English articles which are conducive to their physical and mental health.

\section{To Integrate the Ideological and Political Education in Listening and Speaking}

Listening and speaking are important abilities for the students, and English teachers also attach importance to train the students' listening and speaking in the class. Take New Standard College English-Real Communication Listening and Speaking 1 published by Foreign Language Teaching and Research Press for example, the topics in the text book are new and close to life that can be regarded as a good text book for listening and speaking. At the same time, some of the topics in this book can also be ideological and political educational. For instance, the topic in unit one is the life of the freshmen in Oxford University and the students can learn how to adapt to the new life in colleges. The teacher can make full use of this listening and ask the students to discuss their challenges and difficulties during the first months of their college life. The teacher can also give the students some help and advice on how to adjust to the new environment. The topic of unit ten is protecting the environment. The teacher can lead the students to the discussion of the environmental pollution in China and make them realize that environmental protection is a critical problem and is closely related to everyone. By learning the relative vocabulary and listening, the students will give the concrete measures for environmental protection according to their common sense and what they have learned in the college. And the students will realize that as the future citizens they have the responsibilities to protect the environment. This subtle influence can also foster their patriotism and general love.

\section{To Integrate the Ideological and Political Education in Translation}

Translation is a very important skill in the first year College English learning. It also can be taught in various ways. The teacher can try to integrate the ideological and political education into College English class. For instance, the 19th National Congress of the Communist Party of China(CPC) was held in October 2017. It is a good opportunity for English teachers to integrate the ideological and political education into the translation class. First of all, the teacher can share the hot words of the 19th National Congress of the CPC with the students, such as the Chinese Dream (中国梦), Stay true to the mission(不忘初心), cultural confidence (文化自信), the Silk Road Economic Belt(丝绸之路 经济带), Innovative and entrepreneurial talent (双创人才) etc. By learning these hot words, the students can better understand the spirit of the conference. After that, the teacher can teach the students how to translate the theme, the terms and the concept of this conference. For example, when translate "As socialism with Chinese characteristics has entered a new era, the principal contradiction facing Chinese society has evolved. What we now face is the contradiction between unbalanced and inadequate development and the people's ever-growing needs for a better life." (中 
国特色社会主义进入新时代, 我国社会主要猫对你已经转化为人民日益增长的美好生活需要和 不平衡不充分的发展之间的矛盾), the students can better understand what our General Secretary means. When translate "When a people have ideals, their country will have strength, and their nation will have a bright future", ( 人民有信仰, 国家有力量, 民族有希望), and “A nation will prosper only when its young people thrive, a country will be full of hope and have a great tomorrow only when its younger generations have ideals, ability, and a strong sense of responsibility”( 青年兴则国 家兴，青年强则国家强。青年一代有理想、有本领、有担当，国家就有前途，民族就有希望。), the students will feel proud to be a Chinese and a sense of responsibility as a young citizen thrive in their hearts. They realize that they must study hard and have a clear design for their future for the sake of the development of the country. Therefore, it is a good chance for the teacher to integrate the ideological and political education when teaching some positive vocabularies or translating some educational messages to the students.

\section{To Integrate the Ideological and Political Education in Writing}

Writing runs through the whole teaching in College English class, and it is weakest ability for the students compared with other abilities. The teacher will not only teach the skills of writing in the class but also assign the writing homework for them. It is feasible to integrate ideological and political ideas in writing assignments. The teacher can assign the writing homework for the freshmen such as the topic on the comparison between the high school life and college life. By comparison, the students discover that the college life is quite different from the high school life. They will walk out of the confusion and then clearly understand their goals. On the other hand, the teacher can also assign a homework on the topic of impact of internet on human relationship. After the students get this assignment, they will first think about the positive and negative influence of internet on their life and study. When they realize that internet has impacted their face to face communication with other people such as their parents, their friends and teachers, they decide to spend more time communicating with those people face to face. They said that they could not indulge in the internet and the virtual world, family and friends are more important.

\section{Conclusion}

As a very important public basic class in college, College English is widely studied and students also pay much attention to. It takes the responsibilities of cultivating students' strong political literacy and international communication and competition. Therefore, the English teachers should face up to this challenge and opportunity and fully take their responsibilities to continually explore and study in their teaching. They can make use of the present textbooks and adjust to the contents and integrate the ideological and political education unconsciously in the reading, listening, speaking, translating and writing. Thus, it not only can improve students' comprehensive abilities, but also can make a contribution to fostering the future talents with high ideological and political consciousness.

\section{Acknowledgement}

This paper was funded by Sichuan University 2017 Ideological and Political Education Project SCUSZ2017015.

\section{References}

[1] 戴炜栋,王雪梅. 双一流背景下的我国外国语言文学学科发展战略 $(\mathrm{J})$. 北京第二外国语学 院学报,2016( 5) : 1 - 13 .

[2] 中共中央, 国务院. 关于进一步加强和改进大学生思想政治教育的意见 $[\mathrm{N}]$. 人民日 报,2004,10,15,(1).

[3] 教育部公布《大学英语课程教学要求》, 中国新闻网 2007-9-26.

(http://www.chinanews.com/edu/kong/news/2007/09-26/1036802.shtml). 
[4] 李捷, 浅谈大学生思想政治教育与英语课堂教学的融合, 科技教育, 2017.02.

[5] 张小红, 大学英语教学中德育渗透的必要性与现实性诉求, 高校英语教学, 2013.02. 